\title{
Developing a Football Basic Techniques Learning Model Through Global Analytical Global Approach
}

\author{
Aldo Naza Putra \\ Physical Education, Universitas Islam 45, Bekasi, Indonesia \\ *Corresponding author. Email: Aldoaquino87@yahoo.com
}

\begin{abstract}
This study aims to develop an exercise model of basic football technical skills through the Global Analytical Global approach for SSB PSTS students aged 6-12 years. Specifically, the objectives of this study are to produce a design model of basic football technique skills through Global Analytical Global approach for students aged 6-12 years and to see whether the model is more effective in improving the basic technical skills of playing football for students aged 6-12 years. This research was conducted on football students of PSTS Club Padang aged 6-12 years. This research used Research and Development (R \& D) model proposed by Borg and Gall. Data collection was done by observation and questionnaire to see the validation of the model tested in the field. Based on the results of data analysis that has been carried out, starting from the process of making the initial draft of the model, revision of the initial model, small group trials, large group trials, the results were very satisfying, where football experts and trainers stated that this model had a positive purpose for improving football playing skills. Variations in this model have good quality in improving playing skills to enrich basic motion since this model was designed based on the principle of practice from the easy to the difficult, and the variations of this model are very attractive for students aged 6-12 years.
\end{abstract}

\section{Keywords: Basic Football Technical Skills, Global Analytical Global}

\section{INTRODUCTION}

Football is a game that is played using the feet, except for the goalkeeper who is allowed to use his hand in the designated area. Football is played by two opposing teams, each of which consists of 10 players and one goalkeeper. The main objective of the football game is to achieve victory by means of the team can put the ball into the opponent's goal as much as possible and on the other hand keep the goal from conceding. The Indonesian National football team was once the feared team in the Asian arena for its beautiful achievements and games. At the 1958 Asian Games in Tokyo Japan, the Indonesian National Football Team won a bronze medal. At the 1987 Sea Games in Jakarta Indonesia and 1991 in Manila Philippine, Indonesia succeeded in donating a gold medal. Over time, the peak in 2013, the Indonesian National football team won the 19th AFF trophy that coach Indra Safri handled at the time. With the achievements and the proactive game of modern football, Indonesian football was dubbed "Brazilnya Asia".

However, this success now remains a memory. The achievements of the Indonesian National football team are not developed and consistent, instead they are decreasing. Proven at the 2009 Sea Games, the Indonesian National Team became the caretaker and was the first to lose 0-2 from the country of Laos which doubles as the host at the time. Had won the AFF U-19 trophy in 2013, the next two years at the 2015 Sea Games in Singapore with almost the same student composition in the 2013 AFF trophy, Indonesian football achievements actually declined because they were only able to occupy fourth place.

Seeing these conditions, the Indonesian National football team has begun to lose confidence in the Asian scene. According to some opinions from homeland football observers, one of the main causes of the failure of Indonesian national football is the lack of attention to the formation of age groups, especially for children in the first rapid growth phase of the age of 6-12 years. Some of them are, there is no form of exercise guide that matches the character of each age group. There are no stages that contain systematics and specific training methods according to the needs of each age group. Whereas to produce a reliable future of football students, it is formed through the formation of students from the first rapid growth phase of 6-12 years with a correct and systematic training process.

There are so many coaching facilities to realize a better future of Indonesian football. It is good in big cities and even in rural areas in Indonesia, one of which is PSTS Tabing soccer school (SSB) in Padang City, West Sumatra. The SSB PSTS Tabing, was once the center of football in Padang City and even West Sumatra, because the SSB often won the competition. In addition, SSB PSTS Tabing also gave birth to reliable students who took part in big clubs competing in Indonesia's highest competition, and even some of them were called to strengthen the Indonesian National football tea 
But over time, the Padang Tabing SSB PSTS which used to be a role model, is now only underestimated. Never mind thinking about achieving and produce excellent students, SSB PSTS is currently not in demand for future students to be used as a training tool. Based on the results of the author's interview with one of Padang's SSB PSTS Tabing coaches, Coach Jay, it was concluded that SSB PSTS did not have a training reference that was appropriate for the age group, especially during the children. There are no interesting training stages according to the needs of students. So that it makes students feel bored and not motivated in carrying out exercise activities. Besides, based on the author's observations during the exercise routine at the SSB PSTS Tabing Padang soccer field, the training unit that is commonly used is described in the following table:

Table 1. Observation Data.

\begin{tabular}{|l|l|c|}
\hline No. & Trainning Program & Access $(\%)$ \\
\hline 1. & Warming Up & 10 \\
\hline 2. & Fundamental & 55 \\
\hline 3. & Game Releted & 15 \\
\hline 4. & Game Situation & 10 \\
\hline 5. & Cool Down & 10 \\
\hline \multicolumn{2}{|l|}{ Total } & 100 \\
\hline
\end{tabular}

Based on the data above, it was concluded that the percentage of exercise description found in the real game session and game situation in the SSB PSTS was low, only $25 \%$. The age of SSB PSTS Tabing students ranging from 6-12 years as the character of children during the first rapid growth period of 6-12 years should take part in training activities in the form of small sided games which are inseparable from the principle of training that should be.The author also believes in the exercises given during drill-based fundamental exercises that make students queue up to get the chance to touch the ball which makes the atmosphere of the exercise monotonous. Even though the children in that phase, have to get a lot of touch experience with the ball, not by taking turns waiting for the opportunity to touch the ball.

Based on the above considerations, the researchers intend to plan a research on the development of an exercise model to improve basic football engineering skills through the Global Analytical Global approach (Playing, Learning, Playing) which refers to the football grassroots program developed by FIFA and the AFC for 6-12 year students.

Global Analytical Global is a model of training for early students in the football grassroots program adopted by FIFA (Federation of International Football Association). Grassroots football is a program that targets boys and girls aged 6-12 years through school, community and club initiatives, where the main goals and principles are to play football, learn and be happy, besides this teaches children the basics of football so they can develop their own physical and mental capacities through games. (FIFA: 2013)
The Global Analytical Global Method is an exercise model that offers a very structured basic situation, training sessions not ignoring the needs of children to play. In principle the Global Analytical Global method is "learning the game of football through playing". So it is very important for all training sessions, especially for early age students (Grassroots) training models that emphasize fun (games), and exercises (activities). In line with what Johan Wolfgang von Goethe conveyed that children choose to be given the stimulation of play rather than on orders [1]

Global Analytical Global Methods are ideas that use the game itself to teach students how to play, with the view that games are the main focus of the GAG Method. The trainer places students in game situations and then narrows the focus of the target. Then move to practice / learning to analyze errors to increase skills and then reenter the larger game that resembles a match to see an increase in children's play. The main part of the Global Analytical Global training method includes games and exercises. The session must include small-sided games as the main component.

\section{METHOD}

The research site was conducted at Tabing City PSTS Football School (SSB) in West Sumatra, in accordance with the SSB's exercise routine schedule. That is; Tuesday, Thursday and Saturday. The execution time of this research began in December 2017 until December 2018. The target or users in this development research were Padang Tabing PSTS students aged 6-12 years, the trial of the product development model was carried out in a trial consisting of experts or soccer experts who have the capacity and are supported by the existence of a football coaching certificate. The experts are expected to be able to directly assist in the development of the basic football engineering training model through the Global Analytical Global approach, both from the level of effectiveness, efficiency, attractiveness and product.

Broadly speaking, the development of training models for basic football technical skills through the Global Analytical Global approach for students aged 6-12 years refers to the model Research and Development (R \& D) model development design consisting of 10 steps. The steps taken are as follows: 1) Research and Information Collecting, 2) Planning, 3) Divelopment of the fliminary from of produck, 4) Preliminary Field Testing, 5) Main Product Revision, 6) Main Field Testing, 7) Operational Product Revision, 8) Operational Field Testing, 9) Final Product Revision, 10) Dissemination and Implementation [2].

After the validation of the initial draft model, the small group trial, the revision, the large group and valiadation trials that the authors have carried out, the continuation in this study will be carried out before and after treatment using True Experimental Design (Pretest-Posttest Only Control Design). The main characteristic of True Experimental is that, the sample used for the experiment as well as the control group is taken randomly from a particular population [3]. In this design there are two 
groups, each of which is chosen randomly (R). the first group is treated $(\mathrm{X})$ and the other group does not. The groups given the treatment are called the experimental group and the group that is not treated is called the control group, then given a pretest to find out the initial state. The effect of treatment (treatment) is (O1: O2). In the actual study, the effect of treatment was analyzed by different tests, using t-test statistics for example. If there are significant differences between the experimental group and the control group, then the treatment given has a significant effect [3].

\section{RESULTS}

\subsection{Small Group Test Results}

Small group trials will obtain data on the ease and attractiveness of the basic football technique skills training model through the Global Analytical Global approach. Research subjects in a small group trial were $12 \mathrm{SSB}$ students.

\begin{tabular}{|c|l|l|}
\hline $\begin{array}{c}\text { Table } 2 . \\
\text { Small } \\
\text { Group } \\
\text { Test } \\
\text { ResultsNo }\end{array}$ & GAG Training Model & \\
\hline 1 & Variation Model 1 & It can be applied because it can already be done \\
\hline 2 & Variation Model 2 & It can be applied because it can already be done \\
\hline 3 & Variation Model 3 & It can be applied because it can already be done \\
\hline 4 & Variation Model 4 & It can be applied because it can already be done \\
\hline 5 & Variation Model 5 & It can be applied because it can already be done \\
\hline 6 & Variation Model 6 & It can be applied because it can already be done \\
\hline 7 & Variation Model 7 & It can be applied because it can already be done \\
\hline 8 & Variation Model 8 & It can be applied because it can already be done \\
\hline 9 & Variation Model 9 & It can be applied because it can already be done \\
\hline 10 & Variation Model 10 & Forms of exercise are not realistic \\
\hline 11 & Variation Model 11 & It can be applied because it can already be done \\
\hline 12 & Variation Model 12 & It can be applied because it can already be done \\
\hline 13 & Variation Model 13 & It can be applied because it can already be done \\
\hline 14 & Variation Model 14 & Forms of exercise are not realistic \\
\hline 15 & Variation Model 15 & It can be applied because it can already be done \\
\hline 16 & Variation Model 16 & It can be applied because it can already be done \\
\hline 17 & Variation Model 17 & Forms of exercise are not realistic \\
\hline 18 & Variation Model 18 & It can be applied because it can already be done \\
\hline 19 & Variation Model 19 & It can be applied because it can already be done \\
\hline 20 & Variation Model 20 & It can be applied because it can already be done \\
\hline 21 & Variation Model 21 & It can be applied because it can already be done \\
\hline 22 & Variation Model 22 & It can be applied because it can already be done \\
\hline 23 & Variation Model 23 & It can be applied because it can already be done \\
\hline
\end{tabular}

Based on the results of the small group trial evaluation conducted, it was concluded that 23 models were selected and 20 models could be applied. Experts recommend adding exercise repetition / frequency to each training material so that students' technical skills become better.

\section{Large Group Trial Results}

Large group trials will be obtained data on the ease and attractiveness of the basic football technique skills training model through the Global Analytical Global approach. Research subjects in a large group trial were 20 SSB students.

Table 3. Large Group Test Result.

\begin{tabular}{|c|c|c|}
\hline No & $\begin{array}{c}\text { GAG Training } \\
\text { Model }\end{array}$ & Information \\
\hline 1 & Variation Model 1 & $\begin{array}{c}\text { Can be implemented } \\
\text { properly }\end{array}$ \\
\hline
\end{tabular}

\begin{tabular}{|c|c|c|}
\hline 2 & Variation Model 2 & $\begin{array}{c}\text { Can be implemented } \\
\text { properly }\end{array}$ \\
\hline 3 & Variation Model 3 & $\begin{array}{c}\text { Can be implemented } \\
\text { properly }\end{array}$ \\
\hline 4 & Variation Model 4 & $\begin{array}{c}\text { Can be implemented } \\
\text { properly }\end{array}$ \\
\hline 5 & Variation Model 5 & $\begin{array}{c}\text { Can be implemented } \\
\text { properly }\end{array}$ \\
\hline 6 & Variation Model 6 & $\begin{array}{c}\text { Can be implemented } \\
\text { properly }\end{array}$ \\
\hline 7 & Variation Model 7 & $\begin{array}{c}\text { Can be implemented } \\
\text { properly }\end{array}$ \\
\hline 8 & Variation Model 8 & $\begin{array}{c}\text { Can be implemented } \\
\text { properly }\end{array}$ \\
\hline 9 & Variation Model 9 & $\begin{array}{c}\text { Can be implemented } \\
\text { properly }\end{array}$ \\
\hline 10 & Variation Model11 & $\begin{array}{c}\text { Can be implemented } \\
\text { properly }\end{array}$ \\
\hline 11 & Variation Model 12 & Can be implemented \\
\hline
\end{tabular}




\begin{tabular}{|c|c|c|}
\hline 12 & Variation Model 13 & $\begin{array}{c}\text { Can be implemented } \\
\text { properly }\end{array}$ \\
\hline 13 & Variation Model 15 & $\begin{array}{c}\text { Can be implemented } \\
\text { properly }\end{array}$ \\
\hline 14 & Variation Model 16 & $\begin{array}{c}\text { Can be implemented } \\
\text { properly }\end{array}$ \\
\hline 15 & Variation Model 18 & $\begin{array}{c}\text { Can be implemented } \\
\text { properly }\end{array}$ \\
\hline 16 & Variation Model 19 & $\begin{array}{c}\text { Can be implemented } \\
\text { properly }\end{array}$ \\
\hline 17 & Variation Model20 & $\begin{array}{c}\text { Can be implemented } \\
\text { properly }\end{array}$ \\
\hline 18 & Variation Model21 & $\begin{array}{c}\text { Can be implemented } \\
\text { properly }\end{array}$ \\
\hline 19 & Variation Model22 & $\begin{array}{c}\text { Can be implemented } \\
\text { properly }\end{array}$ \\
\hline 20 & Variation Model 23 & $\begin{array}{c}\text { Can be implemented } \\
\text { properly }\end{array}$ \\
\hline
\end{tabular}

Based on the results and evaluation of large group trials, it can be concluded that all models can be applied well, plus the quality of training to improve the basic skills of football students is achieved, in addition to this exercise model has a high appeal that makes students happy in carrying out the exercises. Football experts and trainers state that this model has a good purpose for improving football playing skills. Variations in this model have good quality in improving playing skills. Variations in this model can enrich basic motion. Variations in this model are arranged based on the principle of practice from the easy to the difficult, and the variation of this model is very attractive for students aged 6-12 years. Thus this model meets all valid criteria that are ready to be used and used as guidelines for trainers in providing training materials to improve basic technical skills in playing football.

\section{CONCLUSION}

Based on the data obtained, starting from the initial draft, revision, the results of small group trials and large group trials and discussion of the results of the study, it can be concluded that the model of basic football technical skills training through Global Analytical Global approach for SSB students aged 6-12 years, overall it is very feasible to use to improve basic technical skills playing football. From the 25 initial concepts of the validated model, 20 models can be said to be eligible to be used as training models to improve basic football engineering skills through the Global Analytical Global approach. This is because based on the discussion of the results of the product trial analysis which includes: (1) training material seen in terms of ease, variety, systematic and the benefits of the exercise itself. (2) training methods based on the effectiveness and attractiveness of the exercise itself.

\section{REFERENCES}

[1] Borg, W.R. \& Gall, M.D, “Educational Research An Introduction," Longman New York; Longman. 1983

[2] Callery, Sean, "Soccer Technuiqe, Taktics, Trainning," Hongkong; The Crowwod Press Ltd, 1991.

[3] Sugiyono, "Educational Research Methods, Quantitative, Qualitative Approachesand $R \& D, "$ Bandung; Alfabeta. 2008. 